\title{
Research on the Economic Benefits of High-speed Railway Enterprise Based on Activity Based Costing Method
}

\author{
Zhengze Yang, Juanqiong Gou \\ School of Economics and Management, Beijing Jiaotong University, 100044, Beijing, China
}

\begin{abstract}
The economic benefits are the basis for survival and development of the enterprises. Although the high-speed railway enterprise has many professions with exquisite division of labor, enormous organizations, complex calculation of economic benefits and other features, studying the economic benefits calculation for the highspeed railway enterprises, analyzing the operation costs and income conditions of high-speed railway and clarifying the economic benefits of high-speed railway enterprises are still the basis to realize the sustained operation of high-speed railway. Based on the analysis of influencing factors of economic benefits in the high-speed railway enterprises, this article sets up a model for economic benefits calculation based on activity based costing and takes the Beijing-Shanghai high-speed railway as an example to calculate its enterprise costs and economic benefits, and finally provides some advice on development policy of high-speed railway. This article may provide a reference for the management and decision-making department of highspeed railway.
\end{abstract}

Keywords. high-speed railway; economic benefits of enterprise; activity based costing

\section{Main factor that influence the economic benefits of high-speed railway enterprise}

The transportation costs of high-speed railway refers to all the expenses induced in the process of transportation to meet the transportation demand for the travelers, mainly including the consumption of capital goods and labor force in the transportation and production process. The capital goods consumption is mainly reflected in the application, repair and depreciation of railway route, station building and bullet train; The labor force consumption is mainly in the labor reward paid to the laborers, such as the wage and subsidy. The gross transportation costs refer to the total expenses induced in the whole process in which, for example, the travelers go from starting station, stay on the train and change train. The unit transportation costs refer to the expense of unit transportation volume (ton $/ \mathrm{km}$ or person $/ \mathrm{km}$ ). There are many factors that influence the economic benefits of high-speed railway, mainly including the fixed assets scale, mode of investment and financing, passenger capacity and the mode of transportation organization, organization and management. 


\section{Analysis on the operation procedure of Chinese high-speed railway}

Same as the existing railways, the products transported in the high-speed railway is also the displacement of traveler, and all the operations of high-speed railway are developed around this core content. Different from the existing railways, the high-speed railway has many features, such as high-speed, high security, high accuracy and high costs, and its operation also has multiple features, such as more focus on the passenger transport marketing, informatization of passenger transport security, centralization of dispatch and integration of maintenance and management. The operations of high-speed railway can be divided into three parts, namely the marketing and passenger transport service, train operation (sub-divided into train station and comprehensive dispatch) and comprehensive maintenance. The content of each part and their interrelations are as shown in Figure 1.

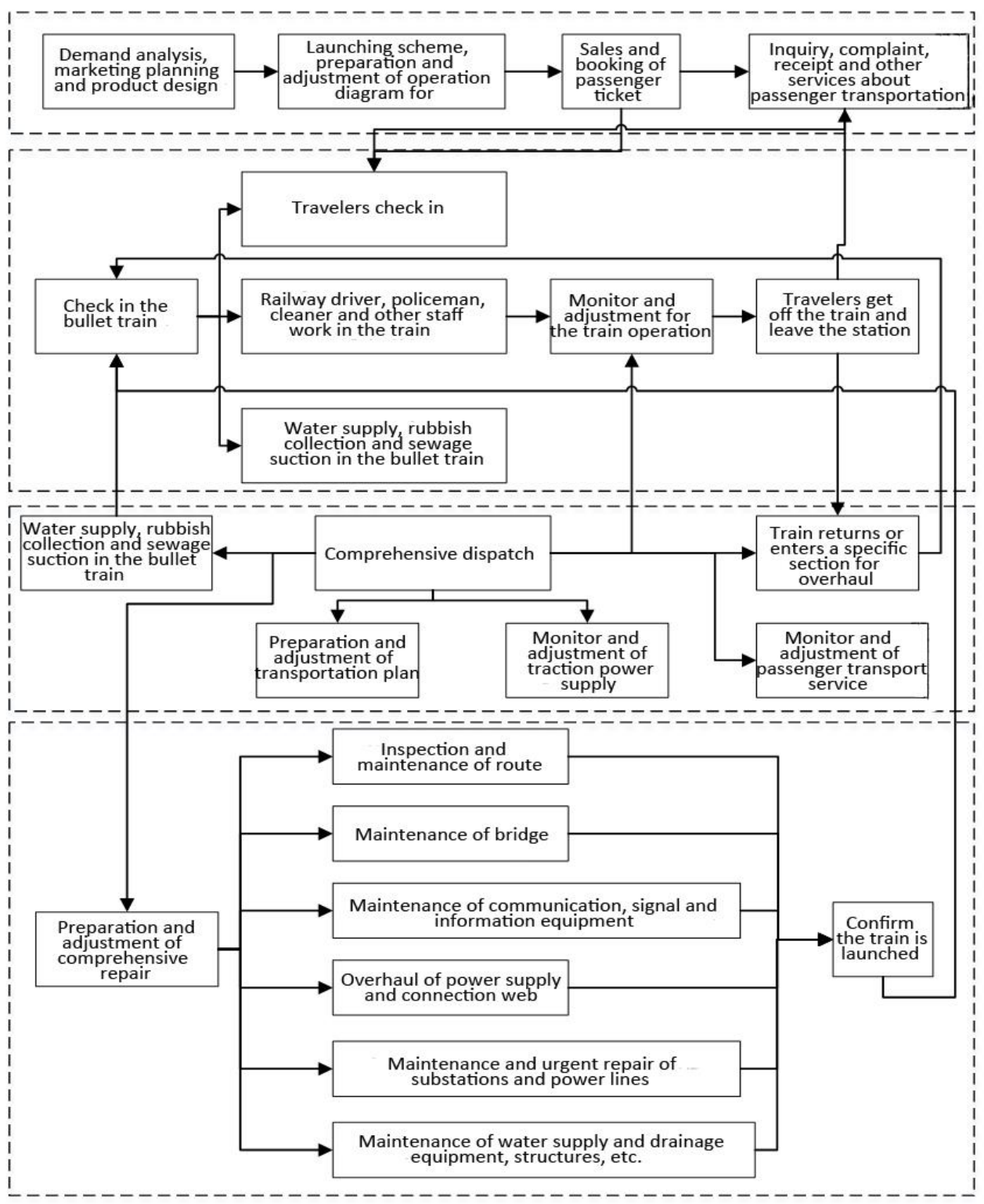

Figure 1. Schematic diagram of Chinese high-speed railway operation and interrelation. 


\section{Costs calculation for high-speed railway enterprise based on activity based costing}

Based on activity based costing, the costs of high-speed railway enterprise can be divided into capital costs and activity costs. The capital costs is the price the enterprise pays to raise funds. The capital costs mainly include two parts, namely the payable expense for assets occupation, which is directly related to the deadline and rate of assets occupation; and the payable expenses of financial intermediate service and relevant labor consumption in the fund raising process. It mainly refers to the relevant expense paid by the financial institution for issuing securities and it's not related to the rate of fund raising or deadline of assets occupation.

In the perspective of resources collection, the resources of high-speed railway can be collected as labor force, station building, route (including road bed, bridge, track, connection web, communication signal equipment, etc.), bullet train, water-power, material, equipment, etc.. In the perspective of collection of resources costs expense, the activity costs of high-speed railway can be divided into artificial costs (including bonus, welfare, etc.), material costs, equipment depreciation costs, water-power costs, maintenance costs, fuel power costs, etc..

The activity based costing takes the activity as the collection objective for the indirect expense, collects the resources expense to the activity through confirmation and measurement of resources agents, and collects the activity costs to product or service through confirmation and measurement of activity agents. High-speed railway is a large system with very complex operational procedure. Based on the above analysis on the operation activity of high-speed railway, the high-speed railway activity will be collectively divided into:

(1) Traveller delivery activity: mainly includes the ticket sale activity of ticket seller in the station, ticket inspection, check-in, security check, inquiry, train waiting, on-board ticket check, off-board and other customer service activities of ticket collector in the station, water supply and rubbish collection when the train stops at a certain station, information conveyance and equipment control of comprehensive control department in the station. Its resources occupation mainly includes labor force, station building, equipment, water-power, etc., and the costs expense include wage, depreciation fee, water-power fee, station building, equipment maintenance, repair and other expenses. The activity index is the number of delivered people.

(2) Train operation activity: mainly includes the launch, stop, operational control, etc. of a bullet train, inspection, maintenance activity, etc. of train mechanic, customer service, train cleaning, etc. of train attendant, planning, preparation, operational monitor, operational adjustment, etc. of relevant comprehensive dispatch staff, power-supply monitor, maintenance, etc. of traction power supply system. Its resources occupation mainly includes labor force, station building, route, bullet train, fuel power expense, etc., and the costs expense include wage, fuel power fee, depreciation fee, material fee and other expenses. The activity index is train kilometer or train hour.

(3) Maintenance and repair activity: mainly includes the repair, overhaul, etc. of bullet train, maintenance and repair of route, bridge, tunnel, track, connection web, signal equipment and other infrastructures. Its resources occupation mainly includes labor force, material, equipment, etc.. The costs expense includes wages, material fee, equipment depreciation fee and other expenses. The activity index is train kilometer or gross ton weight kilometer

(4) Customer service activity: (1) marketing activity: formulate and adjust relevant activities such as launching scheme and operation diagram for the train, according to the changes in passenger flow. Its resources occupation mainly includes labor force, equipment, office buildings, etc.. The costs expense includes wages and equipment depreciation fee. The activity index is the number of times for which the operation diagram is adjusted. (2) Customer service activity: mainly includes the railway 12306 telephone and relevant customer service and maintenance activity in the website. Its resources occupation mainly includes labor force, equipment, water-power fee, etc.. The costs expense includes wages, depreciation fee, water-power fee, etc.. The activity index is the number of served people. (3) Ticket activity: mainly includes booking, sales, calculation and other 
activities. Its resources occupation mainly includes labor force, material, equipment, etc.. The costs expense includes wages, material fee, equipment depreciation fee, etc..

See the research case of Beijing-Shanghai high-speed railway for the activity division, index and costs of high-speed railway.

\section{Analysis on the economic benefits of Beijing-Shanghai high-speed railway}

\subsection{Overview of Beijing-Shanghai high-speed railway}

The whole length of Beijing-Shanghai high-speed railway is $1,318 \mathrm{~km}$ through 3 major municipalities directly under the central government, namely Beijing, Tianjin and Shanghai, and four provinces, namely Hebei, Shandong, Anhui, and Suzhou. It connects two major economic zones, namely Bohai and Yangtze River Delta. The total investment is about 220.9 billion yuan, and 23 train stations have been established. The design speed of infrastructure is $380 \mathrm{~km} / \mathrm{h}$, and the current operational speed is reduced to $300 \mathrm{~km} / \mathrm{h}$. The investment bodies of Beijing-Shanghai highspeed railway include CRIC that represents China Railway Corporation, Beijing City, Hebei Province, Tianjin City, Shandong Province, Anhui Province, Jiangsu Province, Shanghai City, etc. along the route of Beijing-Shanghai that make investment from land acquisition and house removal, and China Pingan, Social Security Foundation, etc. that become a shareholder by investing currencies.

\subsection{Costs calculation for Beijing-Shanghai high-speed railway based on activity based costing}

\subsubsection{Activity costs}

According to the prediction for passenger transport capacity, Beijing-Shanghai high-speed railway is expected to deliver the travelers in 158 million person-time. This article takes the year 2020 as the objective year, and calculate the expenses of transportation activity respectively according to the division of delivery activity, operational activity, repair activity and customer service activity. Then we refer to other relevant parameters of high-speed railway [2-9] to calculate the activity costs of Beijing-Shanghai high-speed railway, as shown in Table 1.

Table 1. Elements of activity index and costs expense of high-speed railway divided according to activity.

\begin{tabular}{|l|l|l|}
\hline Name of activity & Activity index & Expense item \\
\hline \multirow{4}{*}{$\begin{array}{l}\text { Delivery activity } \\
\text { in train station }\end{array}$} & $\begin{array}{l}\text { Number of } \\
\text { delivered people }\end{array}$ & $\begin{array}{l}\text { Service expense of security check, ticket inspection, inquiry, } \\
\text { rubbish collection, comprehensive control, off-station ticket } \\
\text { check, etc. }\end{array}$ \\
\cline { 3 - 3 } & $\begin{array}{l}\text { Depreciation fee and water-power fee of station building and } \\
\text { equipment }\end{array}$ \\
\cline { 3 - 3 } & $\begin{array}{l}\text { Maintenance, repair and other expenses of station building and } \\
\text { other relevant equipment }\end{array}$ \\
\cline { 3 - 3 } $\begin{array}{l}\text { Operational } \\
\text { activity }\end{array}$ & Train hour & $\begin{array}{l}\text { Relevant expense of driver, attendant, train cleaner, } \\
\text { comprehensive controller and other staff }\end{array}$ \\
\cline { 2 - 3 } & Train kilometer & Depreciation, repair and overhaul fee of bullet train \\
\cline { 2 - 3 } $\begin{array}{l}\text { Maintenance and } \\
\text { repair activity }\end{array}$ & Ton kilometer & Fuel power fee of bullet train \\
\hline
\end{tabular}




\begin{tabular}{|c|c|c|c|c|c|}
\hline Name of activity & Activity index & \multicolumn{4}{|c|}{ Expense item } \\
\hline & & \multicolumn{4}{|c|}{$\begin{array}{l}\text { Depreciation fee for the fixed facilities such as route, bridge, } \\
\text { tunnel and connection web }\end{array}$} \\
\hline $\begin{array}{l}\text { Customer service } \\
\text { activity }\end{array}$ & $\begin{array}{l}\text { Number of } \\
\text { served people }\end{array}$ & \multicolumn{4}{|c|}{$\begin{array}{l}\text { Expenses induced when the marketing departments formulate } \\
\text { the launching scheme, prepare or adjust the operational } \\
\text { diagram, the expenses shared by railway customer server, and } \\
\text { the expenses induced from calculation of ticket fare and assets, } \\
\text { and other financial expenses. }\end{array}$} \\
\hline Name of activity & Activity index & Wage & Depreciation & Water-power & Power \\
\hline \multirow{3}{*}{$\begin{array}{l}\text { Delivery activity } \\
\text { in train station }\end{array}$} & \multirow{3}{*}{$\begin{array}{l}\text { Number of } \\
\text { delivered people }\end{array}$} & 40185.75 & & & \\
\hline & & & 20054.40 & 42887.5 & \\
\hline & & & & & \\
\hline \multirow{3}{*}{$\begin{array}{l}\text { Operational } \\
\text { activity }\end{array}$} & Train hour & 39386.13 & & & \\
\hline & Train kilometer & & 294000 & & \\
\hline & Ton kilometer & & & & 1059955 \\
\hline \multirow{2}{*}{$\begin{array}{l}\text { Maintenance and } \\
\text { repair activity }\end{array}$} & \multirow{2}{*}{ Train kilometer } & 34084.5 & \multicolumn{3}{|c|}{191129.11} \\
\hline & & & 444342.60 & & \\
\hline $\begin{array}{l}\text { Customer service } \\
\text { activity }\end{array}$ & $\begin{array}{l}\text { Number of } \\
\text { served people }\end{array}$ & \multicolumn{4}{|c|}{15822.49} \\
\hline Name of activity & Activity index & Material & Repair & Other & Subtotal \\
\hline \multirow{4}{*}{$\begin{array}{l}\text { Delivery activity } \\
\text { in train station }\end{array}$} & \multirow{4}{*}{$\begin{array}{l}\text { Number of } \\
\text { delivered people }\end{array}$} & & & & 40185.75 \\
\hline & & & & & 62941.9 \\
\hline & & & 16250 & & 16250 \\
\hline & & & & 4018.58 & 4018.58 \\
\hline \multirow{3}{*}{$\begin{array}{l}\text { Operational } \\
\text { activity }\end{array}$} & Train hour & & & 3323.05 & 42709.18 \\
\hline & Train kilometer & & 423360 & & 717360 \\
\hline & Ton kilometer & & & & 1059955 \\
\hline \multirow{2}{*}{$\begin{array}{l}\text { Maintenance and } \\
\text { repair activity }\end{array}$} & \multirow{2}{*}{ Train kilometer } & \multicolumn{3}{|c|}{191129.11} & 225213.61 \\
\hline & & & & & 444342.60 \\
\hline $\begin{array}{l}\text { Customer service } \\
\text { activity }\end{array}$ & $\begin{array}{l}\text { Number of } \\
\text { served people }\end{array}$ & \multicolumn{3}{|c|}{15822.49} & 15822.49 \\
\hline
\end{tabular}

Then calculate and summarize the activity index volume, activity costs for a whole year, gross activity costs and unit activity costs for each activity center of Beijing-Shanghai high-speed railway, as shown in Table 2 .

\subsubsection{Estimation of capital costs}

As shown in the publicized data, the total investment of Beijing-Shanghai high-speed railway is 220 billion yuan, with project capital 110 billion yuan, among which CRIC represents China Railway Corporation to invest 40 billion yuan; ICBC, BOC, CCB, China Pingan, National Social Security Foundation, etc. jointly invest totally 50 billion yuan; the local governments purchase the stocks of 20 billion yuan with land acquisition and house removal, and the other 110 billion yuan consists of issued securities and bank loan.

Currently, the prime interest rate for fixed deposit of 5 years in Chinese banks is $4.75 \%$, which may be considered as risk-free income. While the interest rate on borrowing released by the central bank is $6.15 \%$. The composition of capital in Beijing-Shanghai high-speed railway can be used to calculate the unit transportation costs of total capital costs and debt capital costs of high-speed railway as follows:

Overall rate of capital costs for Beijing-Shanghai high-speed railway:

$4.75 \% \times 50 \%+6.15 \% \times 50 \%=5.45 \%$

Total costs of capital in Beijing-Shanghai high-speed railway: 
$2209 \times 5.45 \%=120.39$ (hundred million yuan)

Debt capital costs: $1100 \times 6.15 \%=67.65$ (hundred million yuan)

Unit transportation costs including the total capital costs:

$(2681375.1+1203900) / 7409430=0.5244$ yuan

Unit transportation costs only including the debt costs:

$(2681375.1+676500) / 7409430=0.4532$ yuan

Table 2. Calculation of activity costs of Beijing-Shanghai high-speed railway.

\begin{tabular}{lllll}
\hline Activity & Index & $\begin{array}{l}\text { Activity volume } \\
\text { for a whole year } \\
\text { (ten thousand) }\end{array}$ & $\begin{array}{l}\text { Activity costs } \\
\text { for a whole year } \\
\text { (ten thousand) }\end{array}$ & $\begin{array}{l}\text { Unit activity costs } \\
\text { (yuan) }\end{array}$ \\
\hline Delivery activity & $\begin{array}{l}\text { Number of } \\
\text { delivered people } \\
\text { Train hour }\end{array}$ & 15822.5 & 123396.2 & 7.7988 \\
$\begin{array}{l}\text { Operational } \\
\text { activity }\end{array}$ & $\begin{array}{l}\text { Train kilometer } \\
\text { Ton kilometer }\end{array}$ & 987.61 & 42709.18 & 1135.5804 \\
$\begin{array}{l}\text { Maintenance and } \\
\text { repair activity }\end{array}$ & Train kilometer & 9873.24 & 717360 & 72.6570 \\
$\begin{array}{l}\text { Customer service } \\
\text { activity }\end{array}$ & $\begin{array}{l}\text { Number of } \\
\text { served people }\end{array}$ & 15822.5 & 1059955 & 0.1113 \\
Other expenses & $\begin{array}{l}\text { 2\% of all the } \\
\text { operational costs }\end{array}$ & - & 669556.2 & 67.8152 \\
Total & Person/km & 7409430.00 & 2681375.1 & 0.3619 \\
\hline
\end{tabular}

\subsection{Economic benefits of Beijing-Shanghai high-speed railway}

Currently, the average transportation price of Chinese Beijing-Shanghai high-speed railway is 0.483 yuan/person per kilometer. According to the deduction from the publicized data, the BeijingShanghai high-speed railway has the income from advertisement (including bullet train and train station) about 70 million yuan, income from stores about 185 million yuan and income from bullet train sales about 43.8 million yuan. According to the predicted passenger transport volume, it is estimated that the Beijing-Shanghai high-speed railway will have the income from advertisement, stores and bullet train sales respectively 105 million yuan, 27.75 million yuan and 65.7 million yuan in the future, by which the economic benefits of Beijing-Shanghai high-speed railway will be calculated, as shown in Table 3.

Table 3. Economic benefits estimation for Beijing-Shanghai high-speed railway.

\begin{tabular}{llll}
\hline Type of costs & Production costs & Consider the debt costs & Total capital costs \\
\hline $\begin{array}{l}\text { Enterprise costs } \\
\text { (ten thousand yuan) }\end{array}$ & 2681375.1 & 3357953.68 & 3885505.09 \\
$\begin{array}{l}\text { Enterprise benefits } \\
\text { (ten thousand yuan) }\end{array}$ & 942199.59 & 265621.01 & -261930.4 \\
\hline
\end{tabular}

As shown in Form 5, according to the predicted number of delivered travelers, the profits, 9.4219959 billion yuan, and the capital income rate, $4.27 \%$, of Beijing-Shanghai high-speed railway are objective if just taking the activity costs into account; if only the debt costs are considered, it may realize a little profits of 2.6562101 billion yuan with capital income rate of just $1.20 \%$; if considering the total capital costs, there will be a loss of -2.619304 billion yuan in 
Beijing-Shanghai high-speed railway. As shown in the above analysis, the debt costs of 110 billion yuan becomes a heavy burden for the sustained operation of Beijing-Shanghai high-speed railway. The Beijing-Shanghai high-speed railway will annually pay the debt interest of 6.765 billion yuan, accounting for $71.80 \%$ of the income under the activity costs condition. From the predicted benefits in 2020 , the debt of 110 billion yuan requires 41 years to be settled, so the debt burden is heavy.

\section{Conclusion}

This article first analyzes the factors that influence the economic benefits of high-speed railway, and it sets up a model to calculate the activity costs and economic benefits in the operation and management mode of high-speed railway according to the activity procedure of Chinese highspeed railway and its operation and management mode based on activity based costing. This article also takes the Beijing-Shanghai high-speed railway as an example to calculate the activity costs under the transportation volume in 2020 and consider the operational costs in debt and capital costs. The calculation and analysis indicate the activity costs of Beijing-Shanghai high-speed railway is 0.3619 yuan/person per kilometer, and the unit costs of high-speed railway when considering the debt costs and capital costs are respectively 0.4532 yuan/person per kilometer and 0.5244 yuan/person per kilometer. So the Beijing-Shanghai high-speed railway has a heavy burden from debt settlement. For the healthy development of Chinese high-speed railway, the management developments are suggested to reduce the business pressure of high-speed railway by reducing the debt interest rate or other methods.

\section{Acknowledgement}

This project is supported by Science and technology research and development plan of China Railway Corporation (Contract No: 2013F017).

\section{References}

1. Liu, J.C. Analysis on the construction cost of high-speed railway and special line project for passenger transport [J]. Construction Cost Management for High-speed Railway Project. 2010, 25(3): 20-23.

2. Li, D.A. Research on the Railway Network Costs and Pricing Problem for Chinese Railway [D]. Beijing: Beijing Jiaotong University, 2006.

3. Chu, N.N. Research on the Costs Benefits of Chinese High-speed Railway [D]. Shijiazhuang: Shijiazhuang Tiedao University, 2013.

4. Fang, Q.G. Research on the estimation of activity based costing for the operational costs in high-speed railway [J]. Journal of Railway Science and Engineering. 2006, 3(5): 87-92.

5. Zhang, S.S. Research on the Estimation of Activity Based Costing for the Special Transportation Line for Railway Passenger Transport [D]. Beijing: Beijing Jiaotong University, 2007.

6. Fang, F.M. Research on the Operational Costs of Special Line for Passenger Transport [D]. Chengdu: Southwest Jiaotong University, 2011.

7. Ma. C.Y. Research on the Transportation Costs Problem of High-speed Railway--Taking the Beijing-Shenyang high-speed railway as an example [D]. Chengdu: Southwest Jiaotong University, 2014.

8. Wang, S.K. Setting scheme and investment analysis for comprehensive repair area [J]. Railway Construction Technology. 2008, (addition): 164-166

9. MFPRC. Notice from Ministry of Finance about Accounting Calculation Method for Railway Transportation Enterprise [S]. 2003. 